\title{
STEAM Education Using Sericulture Ukiyo-e: Object-Based Learning through Original Artworks Collected at a Science University Museum in Japan
}

\author{
Sayuri Tanabashi ${ }^{1 *}$
}

${ }^{1}$ Nature and Science Museum, Tokyo University of Agriculture and Technology, JAPAN

*Corresponding Author: sayuri.m.tanabashi@gmail.com

Citation: Tanabashi, S. (2021). STEAM education using sericulture ukiyo-e: Object-based learning through original artworks collected at a science university museum in Japan. Interdisciplinary Journal of Environmental and Science Education, 17(4), e2248. https://doi.org/10.21601/ijese/10962

\begin{tabular}{ll}
\hline ARTICLE INFO & ABSTRACT \\
\hline Received: & Societies across the world face the need to increase the number of science, technology, engineering, \\
13 November 2020 & $\begin{array}{l}\text { and mathematics (STEM) personnel who could resolve issues concerning sustainability. The body } \\
\text { of scholarly literature on STEM education has grown significantly since the beginning of the }\end{array}$ \\
& 21st century. STEAM education incorporates arts with STEM subjects. This pedagogical strategy is \\
Accepted: & increasingly adopted in formal/informal education settings to foster scientific thinking and \\
creativity through multisensory artistic activities. Science museums and centers house discrete & items such as multi-touch tabletops that allow visitors to handle objects and engage in experiential \\
& activities. This study postulates that science university museums can contribute to STEAM \\
& education. It illustrates the effectiveness of object-based learning (OBL) in STEAM education \\
& imparted through original artwork housed in science university museums. This study's application \\
& of OBL at university museums establishes OBL within cross-disciplinarySTEAM-based educational \\
& systems in Japan through the use of original artwork such as sericulture ukiyo-e. \\
& Students majoring in agriculture or technology participated in the workshop designed for this \\
& study, directly engaged with discrete multisensory sericulture ukiyo-e, and were encouraged to \\
& think from diverse perspectives. Finally, the studentsdebated the sericulture ukiyo-e and organized \\
& an exhibition. This study concludes that the academic value of STEAM education is enhanced \\
& through the technique of fostering problem-solving in students using interactions with and active \\
& discussions about artwork collections and objects.
\end{tabular}

Keywords: STEAM education, object-based learning, interdisciplinary, ukiyo-e, university museums

\section{INTRODUCTION}

Societies across the world face the need to increase the number of science, technology, engineering, and mathematics (STEM) personnel to problem-solve sustainability-related issues on a global scale (National Research Council, 2012). Certainly, the body of scholarly literature pertaining to STEM education has grown significantly since the beginning of the $21^{\text {st }}$ century. The notion of STEM education has historically been widely influenced by the national policies of the United States (Breiner et al., 2012; Shanahan et al., 2016). The acronym STEM integrates individual disciplines with the aim of using them in conjunction to resolve real-world difficulties (Sanders, 2009). STEM curricula were incorporated to accord students the opportunity to develop $21^{\text {st- }}$ century skill sets that could ameliorate decisionmaking related to personal health, energy efficiency, environmental quality, resource use, and national security, and other issues clearly linked to knowledge of STEM disciplines (Bybee, 2010). STEM education is globally associated with strategies undertaken by various countries and regions to foster STEM personnel able to lead innovation. In particular, such strategies appear to emphasize the integration

Copyright $(C) 2021$ by Author/s and Licensed by Veritas Publications Ltd., UK. This is an open access article distributed under the Creative Commons Attribution License which permits unrestricted use, distribution, and reproduction in any medium, provided the original work is properly cited. 
between the STEM disciplines to offer students a rigorous and meaningful experience of the real world rather than highlighting individual elements (e.g., Sanders, 2009; Yoon et al., 2014) without the traditional barriers that have divided individual disciplines (Vasquez et al., 2013). The stronger associations between the sciences and mathematics were advocated by the initial discourse of the STEM movement to develop engineers (Moore, 1903) and other allied professionals through the integration of design and technology (Bryan et al., 2015). Especially, the interdisciplinarity/transdisciplinarity of STEM education is regarded important (Takeuchi et al., 2020). The pedagogic strategy of science, technology, engineering, arts, and mathematics (STEAM) education has recently gained traction. This methodology incorporates the arts into STEM education in both formal and informal education settings to encourage scientific thinking as well as creativity through multisensory artistic activities (Liao, 2016; Rolling, 2016; Segarra et al., 2018). Unlike STEM education, the STEAM methodology cannot yet be adequately defined because of the continuing uncertainty about the arts to be studied within its ambit. Although educational policies relating to STEAM are now universally recognized and are being accelerated, a common understanding of the component of art is yet to be achieved. In fact, various active learning or teaching methods, such as problem-based learning, have been proposed recently (e. g., Rillero et al., 2020). Such debates also continue in the domains of science education in Japan.

Science museums and centers are considered informal education institutions where visitors can develop scientific thinking and experience multisensory artistic activities (Mujtaba et al., 2018) that are suited to STEAM education (e.g., Rolling, 2016). Science museums and centers house myriad items such as multi-touch tabletops that can be handled by visitors who desire to engage in experiential activities (e.g., Horn et al., 2012; Mujtaba et al., 2018). Thus, science university museums can also contribute to STEAM education. Generally, university museums are distinguished from general repositories through two characteristics (Lourenço, 2008; Simpson et al., 2019). First, they are suited to examinations pertaining to museum studies because university museums are educational and research institutions and represent faculties/departments within their parent university. Second, they are meant to be utilized by research professionals including professors, curators, and librarians who practice interdisciplinary education and research. University museums may thus become pivotal as common academic and cultural resources that facilitate the interaction of the past and present interdisciplinary knowledge in the interests of the future problem-solving efforts directed at global issues (Nykänen et al., 2018). The present paper illustrates the effectiveness of object-based learning (OBL) in STEAM education through the experiencing of original artworks housed in science university museums.

OBL refers to a type of experiential learning (Kolb, 1984) and is a powerful pedagogy involving collections and objects displayed in repositories (Chatterjee et al., 2015). The term "object" in this context indicates traditional handicrafts, archaeological relics, natural history specimens, and also 3-D printed artifacts (Jones, 2012; Wilson et al., 2017). OBL was initially conceived in the domains of educational psychology, cognitive psychology, science education, and museum pedagogy (Paris, 2002). It was obviously predicated on the value of engaging with collections and objects to mediate meaning and context (Hooper-Greenhill, 2007). OBL through multisensory activities has also been proposed to encourage learning through embodied experience, to make sense of learning through constructivism, and to contribute to the diversity of learning contexts (Falk and Dierking, 2000). OBL is a method of mutual experiential learning, characteristically through the use of collections and objects in a museum setting (e.g., Marie, 2010). Despite being mooted in the 19th century, scholars renewed their focus on the benefits and advantages of OBL at the beginning of the $21^{\text {st }}$ century through diverse case studies that applied this pedagogical theory to the higher education sector, apparently initiating a renaissance (Jacobs et al., 2009; Simpson, 2014; Thogersen et al., 2018). Recently, higher education institutions such as universities have extensively reconceived and revived OBL, particularly in the United Kingdom and in Australia (e.g., Hannan et al., 2013; Kador et al., 2018; Simpson, 2014).

The current revival of OBL is palpably different from the conventional conception of the pedagogy in various ways. First, unlike traditional OBL, the current revival of OBL was introduced to higher educational institutions including universities as an effective method of interdisciplinary learning. The contemporary version of the academic framework of OBL also applies it to university museums (Chatterjee et al., 2015), acknowledging its efficacy as a form of experiential learning through the collections, objects, and the museum staff at universities/university repositories.

The contemporary revival of OBL has consequently also triggered an accumulation of studies related to its progression into the higher 
education sector since the beginning of the 21st century. Simpson and Hammond (2012) have demonstrated that three-dimensional substantial objects were more useful for learning at Macquarie University than two-dimensional digital images. Eccles (2019) has evinced that the digitization of collections and objects at the University of Oxford provided students the facility to achieve OBL in virtual space as a complement to traditional textbased learning. Chatterjee (2010) has evinced the extensive range in which OBL may be applied at University College London (UCL), from museum education to medical welfare in a hospital setting. Interestingly, UCL has developed OBL as an institutional strategy and has established more than 100 course-units associated with OBL (Duhs, 2010). UCL's students have responded to this initiative, saying OBL has exerted a positive influence on the advancement of their knowledge (Sharp et al., 2015). According to Kador et al. (2018), UCL's museum educator listed a museum curating course for students to help interested learners identify specimens, perform ethical operations on human samples, or construct digital archives. The application of OBL in museums is thus expected to extend beyond previously developed teaching and learning of specific disciplines that have evinced a traditional affinity for museums. OBL can be pivotal for both discipline-specific content and interdisciplinary studies that transcend the boundaries of particular educational domains (Simpson, 2014, 2019). The present study proposes a type of interdisciplinary STEAM education that can be accelerated through OBL involving original art collections and objects housed at science university museums in Japan.

\section{Aims}

Postulating that science university museums can contribute substantially to STEAM education, this study attempted to apply OBL to Japanese interdisciplinary STEAM-learning. To this end, it utilized original collections and objects housed in a university museum, presenting them to students who participated in a curating workshop organized in a science university museum.

\section{The Experimental Environment and the Participants}

This study was conducted with students majoring in either agriculture or technology who participated in a curating workshop organized at the Nature and Science Museum of the Tokyo University of Agriculture and Technology.

Nature and Science Museum was initially established in 1886 as a reference exhibition room at the Tokyo University of Agriculture and Technology, a national science and engineering institution of higher learning at that time. This museum's parent university has buttressed the sericulture and textile industries and has accomplished diverse Japanese innovations for these sectors. Nature and Science Museum thus holds, preserves, and displays more than 13,000 in-house objects related to the sericulture and textile industries. The artifacts held by this museum range from cocoon and silk specimens to varied fibers and textile machines.

Currently, the Tokyo University of Agriculture and Technology comprises the two faculties reflected in its nomenclature, and students may major in either. The Faculty of Agriculture encompasses five departments $^{1}$, and the Faculty of Technology incorporates six departments ${ }^{2}$. These faculties/departments were originally designed by the institution to lead research and educational activities related to sericulture and the textile industry. Students of this university learn advanced science and technology and are trained to become promising STEM personnel. The museum's collections and objects are not currently utilized for object-based lessons for curricula imparted in classrooms unless they belong to pre-Showa eras. Therefore, students are accorded few opportunities to engage with the museum's collections and objects developed in the course of the university's own education and research activities.

\section{THE EXPERIMENTAL MATERIAL AND PROCEDURE}

The utilization of museum collections and objects for learning and teaching was traditionally restricted to museum-specific disciplines such as natural history, archaeology, and ethnology. For instance, Japanese ukiyo-e originated in the Edo era (16031868) and depicted Japanese customs and landscapes through drawing or printing. This ukiyo-e became learning objectives for students majoring in the arts. The contemporary revival of OBL advocates the utilization of collections and objects housed in university museums for cross-disciplinary learning and teaching. Thus, students of diverse faculties and departments may use ukiyo-e to learn reciprocally. They can interact with these artifacts through multisensory learning using sight and touch and contemplate the art objects not just from the perspective of art history but also from the lens of anthropology, chemistry, or computing to engage broadly in learning, teaching, and research.

Sericulture ukiyo-e was defined as the object for the OBL to be accomplished in this study. The term sericulture signifies silk farming, and more than 400 objects related to this activity have been restored and preserved in Nature and Science Museum. Sericulture 
ukiyo-e records the process of sericulture undertaken by women and represents the process that begins with the growing and cocooning of the silkworm to the reeling of the silk. Originally, sericulture ukiyo-e were drawn and printed between the Edo and the Meiji eras (1868-1912). These works were enthusiastically collected by professors, who studied and taught the history of silk-reeling technology at the university through the Showa era (1926-1989). A sericulture ukiyo-e usually depicts one or more beautiful images of sericulture landscapes accompanied by ancient Japanese writing that is difficult to read or understand for those who know modern Japanese.

Approximately 200 students majoring in agriculture or technology participated in the curating workshop twice, among them, Group A included 222 students majoring in biotechnology and life science, biomedical engineering, applied chemistry, applied physics, and chemical engineering, and included 227 Group B which comprises students majoring in mechanical systems engineering and electrical engineering and computer science; they were given the opportunity to directly engage with numerous sericulture ukiyo-e through multisensory means (Figure 1). Sericulture ukiyo-e was known as printed series but was not translated into modern Japanese script. Thus, the meaning of the ancient writing has not been deciphered in detail. The participating students scrutinized, touched, interpreted, and ultimately deliberated on this sericulture ukiyo-e through the scope of their individual knowledge and organized a student exhibition to showcase the achievements they obtained through the experiential workshop activities of interdisciplinary learning (Allen, 2004; Sand, 2017; Semper, 1990). Students represented not only accomplishments of the interpretation of ancient writing but also contents of the advanced research on sericulture (Figure 2). This curating workshop was conducted as an intensive lecture on the liberal arts program once in April 2020 and again in February 2020 wherein the workshop was piloted for few students and in February 2020 (Table 1). However, majority of the work in the curator workshop, such as survey of the object information and creation of panels, were performed online, except actually observing and touching material objects, including those for ukiyo-e, which was performed while students maintained a suitable physical distance between them.

\section{Quantitative analysis: Selective questionnaire}

This study examines the effectiveness and practicality of OBL using a questionnaire pre- and post-workshop. Students were instructed to answer (Q1) "Are you interested in sericulture-related

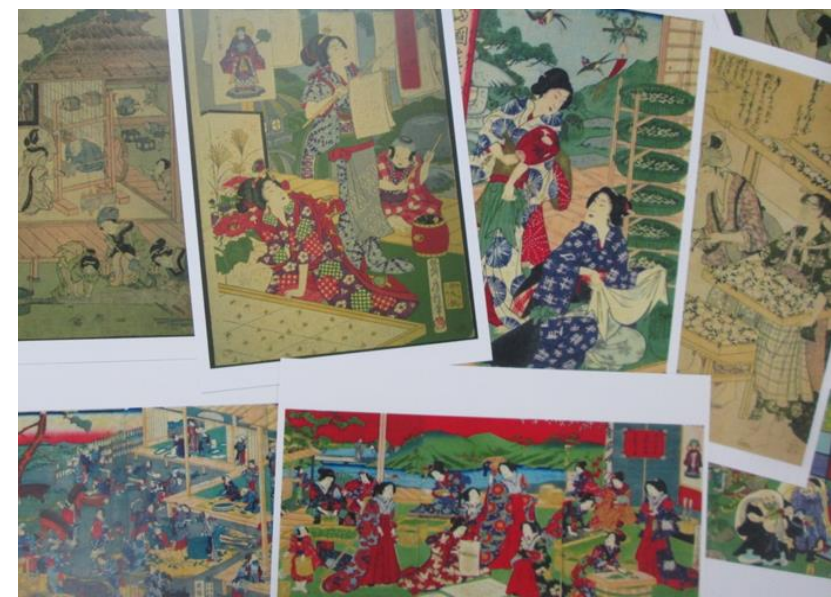

Figure 1. Sericulture Ukiyo-e

studies?" (Figure 3). Responses were rated on a fivepoint scale $(\mathrm{i}=$ Very interested, $\mathrm{ii}=$ Interested, $\mathrm{ii}=$ Neutral, iv $=$ Slightly interested, and $\mathrm{v}=$ Uninterested). Additionally, after the workshop, they were instructed to respond to (Q2) "Did you enjoy cross-disciplinary learning and the multisensory experience with authentic original artworks of sericulture ukiyo-e?" and (Q3) "Did you enjoy the multisensory experience with authentic original artwork sericulture ukiyo-e?" Responses were rated on a five-point scale $(\mathrm{i}=$ Yes, $\mathrm{I}$ did well, $\mathrm{ii}=$ Yes, $\mathrm{I}$ did, $\mathrm{iii}=$ Neutral, $\mathrm{iv}=$ No, I did not, and $\mathrm{v}=$ No, I did not at all.).

Comparing the pre- and post-workshop responses for Q2, this study observed that interest in the postworkshop tended to increase. As previously mentioned, the curating workshop was held twice for approximately 200 students in different groups. Figure 4 illustrates that students' interest relatively increased during the pre-workshop compared with post-workshop. Thus, this study infers that OBL can stimulate learner motivation through multisensory engagement or the ability of authentic items to attract attention. Moreover, Q3 reveals that many students enjoyed cross-disciplinary learning with students majoring in different disciplines. From this perspective, sericulture ukiyo-e played the unique role of a mediator between students majoring in different disciplines.

\section{Qualitative analysis: Open-end questionnaire}

The effectiveness of OBL was surveyed through the implementation of open-ended questionnaires administered to the students who participated in the workshop. The items of the questionnaire queried opinions ranging from the museum curating of sericulture ukiyo-e to sericulture-related aspects pertaining to their respective disciplines. Some 


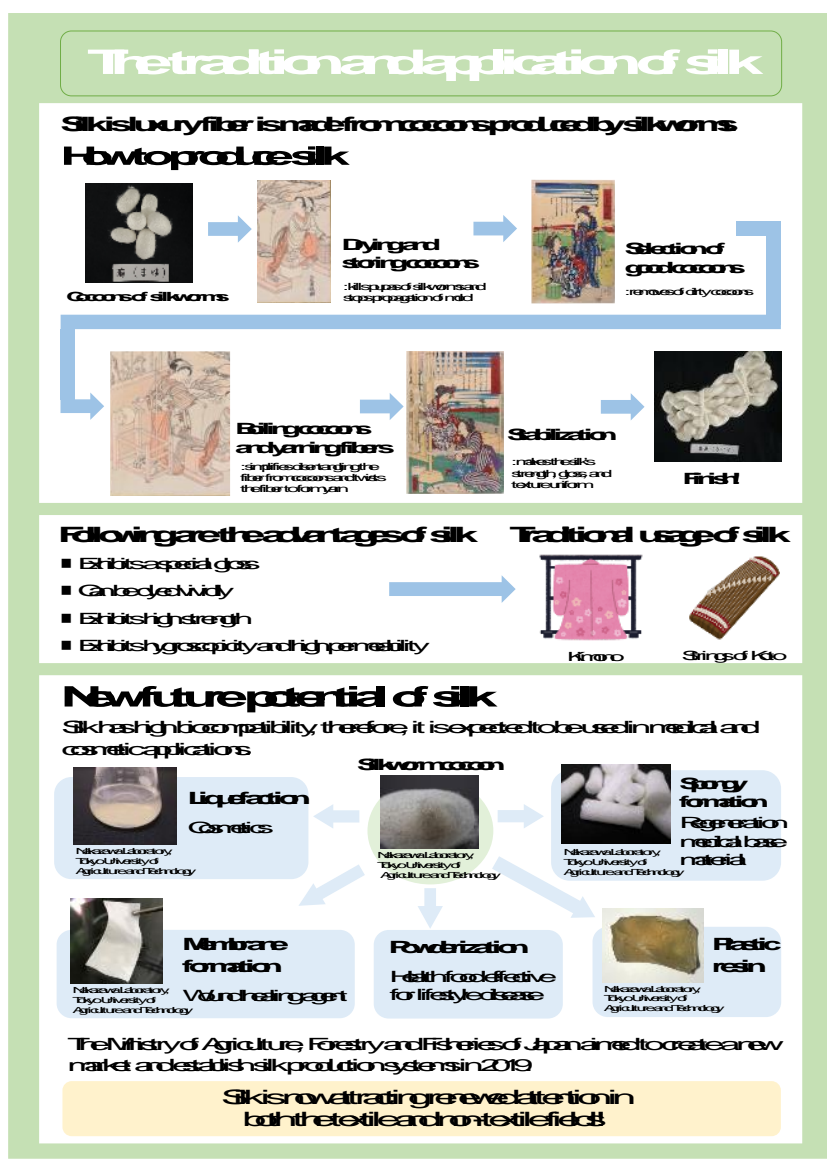

\section{Shi nban Yousan Hanei Sugor oku (1876)}

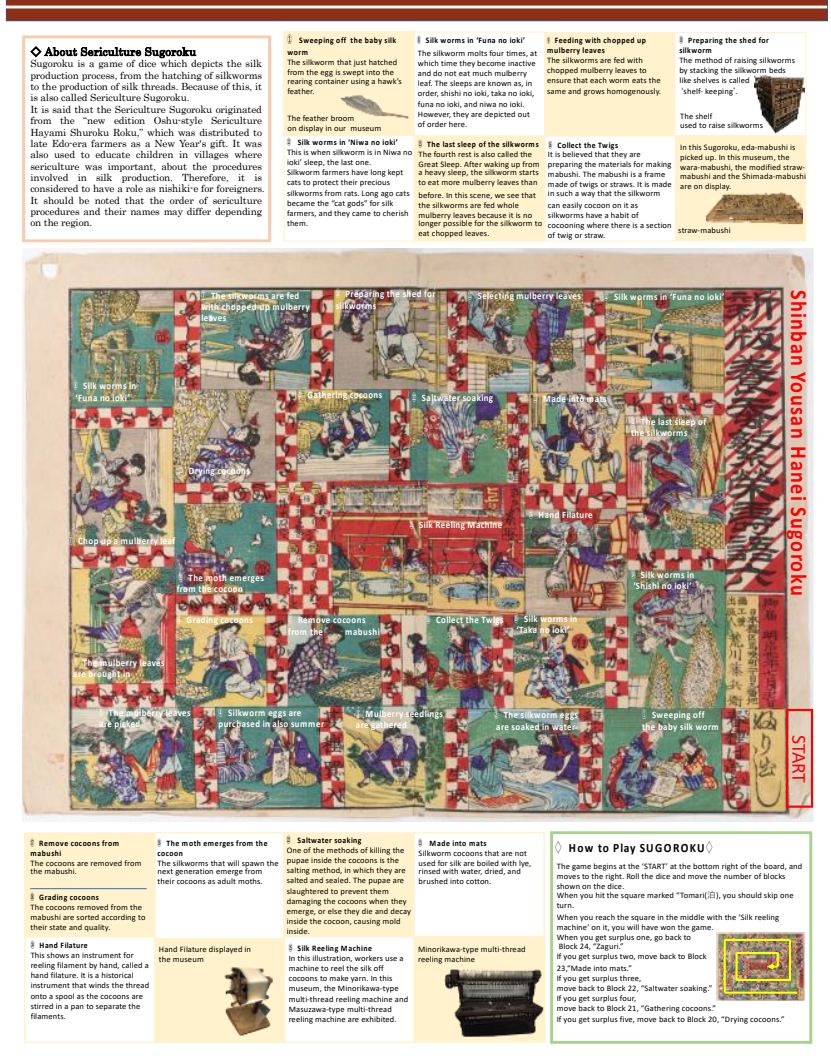

Figure 2. Panel examples of the student exhibition

excerpts of the opinions articulated by the students are reproduced below.

According to Student A, "The models are predominantly females, and the clothing is glossy (as opposed to the actual work), which seems to be the printing of beauty than that of the actual sericulture landscape." She focused on the beauty depicted in Sanshoku ukiyo-e and was attracted to the vivid colors. Certainly, Sanshoku ukiyo-e is one of the oldest and most beautiful pieces of evidence relating to valuable industrial and technological history.

Student B wrote:

Sanshoku ukiyo-e were painted from the late Edo era to the Meiji era. In some works of the Meiji era, it was depicted that the Emperor was observing the work of sericulture, which shows the connection between the Imperial Family and the sericulture industry.

She surveyed the association between sericulture and the Imperial Family. Beginning from the Meiji era, the Empress has inherited the work of sericulture in the Imperial Palace through generations, perhaps considering sericulture to be the symbol of the heart of Japanese females.

Student $\mathrm{C}$ opined that:

Studies on silkworms have also played an important role in basic biology including genetics, embryology, and physiology. In fact, silkworm research has contributed to the proof of the Mendelian inheritance law, the isolation and the identification of sex pheromones and other hormones, and the isolation of mRNA in eukaryotes. At present, research results, such as the creation of genetically modified silkworms and the decoding of the outline of the silkworm genome, have been obtained.

He traced and highlighted the historical utility of silkworms from the past to the present through the scope of biology. It is particularly interesting that applied entomology is a unique discipline and he looked at silkworms in terms of the implementation of experimental materials.

Student D wrote, "Silk has high biocompatibility and thus is expected to be used in medical and cosmetic applications. Liquefaction and cosmetics. 
Table 1. Timeline of the curator workshop

\begin{tabular}{|c|c|c|c|}
\hline Steps & & & Date \\
\hline Step 1 & $\begin{array}{l}\text { Pilot curator } \\
\text { workshop }\end{array}$ & $\begin{array}{l}\text { An announcement was made for the recruitment of participants regarding } \\
\text { the pilot curator workshop that had commenced. }\end{array}$ & $2 / 6 / 2020$ \\
\hline Step 2 & & $\begin{array}{l}\text { A museum visit was held for } 34 \text { students so that they could appreciate the } \\
\text { beauty of material objects, including ukiyo-e, and interact with one another } \\
\text { and their professor. }\end{array}$ & $2 / 10 / 2020$ \\
\hline Step 3 & $\begin{array}{l}\text { Formal } \\
\text { curator } \\
\text { workshop }\end{array}$ & $\begin{array}{l}\text { An announcement was made for the recruitment of participants regarding } \\
\text { the formal curator workshop that had commenced. }\end{array}$ & $4 / 1 / 2020$ \\
\hline Step 4 & & $\begin{array}{l}\text { A workshop was conducted for } 449 \text { students that involved meeting and } \\
\text { introducing participants, in addition to providing a brief on the objectives } \\
\text { of the workshop virtually. }\end{array}$ & $4 / 13 / 2020$ \\
\hline Step 5 & & $\begin{array}{l}\text { A virtual museum visit was held twice for } 222 \text { and } 227 \text { students } \\
\text { respectively, so that they could appreciate the beauty of materials objects, } \\
\text { including ukiyo-e, and interact with each other, the curator, and their } \\
\text { professor. }\end{array}$ & $\begin{array}{l}4 / 15 / 2020 \\
4 / 17 / 2020\end{array}$ \\
\hline Step 6 & & $\begin{array}{l}\text { Students leaned ukiyo-e contents by interacting among themselves and/or } \\
\text { individually to create the panel for student exhibition. }\end{array}$ & $4 / 23 / 2020$ \\
\hline Step 7 & & Students were asked to answer questionnaires. & $5 / 12 / 2020$ \\
\hline
\end{tabular}

Membrane formation and wound healing agent. Powderization; health food effective for lifestyle disease. Spongy formation; regeneration medical base material." She proposed the development of silk materials using advanced technology. From the perspective of material science underpinned by technological innovation, various states of silks may be applied to varied aspects of human life. The students are preparing in collaboration to exhibit their achievements on a digital platform.

This study illustrated that the participating students learned in multifarious ways once they had understood how to handle objects and could interact with each other about noteworthy sericulture ukiyo$e$. They attained fresh information and perspectives about the historical attributes of sericulture on the basis of the seminal role played by their institution and learned how to develop their understanding of the subject for use in the future with personnel specializing in diverse research fields.

After the curating workshop, student E reported:

What I felt most through this museum study was that the collaboration and fusion of different fields through exhibits was very useful not only for museums but also for researchers. I think that we have also been able to improve the involvement of males and females. This practice did not completely lead to new ideas or perspectives in my research field, but it helped increase my knowledge of my field, how it is related to other fields, and what is its social position. With such an objective perspective of specialized fields, I think that interesting ideas can be obtained in the daily life, not to mention at museums, by linking with specialized fields. A museum where many exhibits and their academic values are explained in an easy-to-understand manner is the best place to cultivate such a viewpoint, and a very important role in education and research as a place to interact with different fields.

\section{Student F believed that:}

The practice this time was to create posters for exhibits at the Museum of Agriculture and Technology. It was more difficult than I had imagined to understand the material and convey it in an easy-to-understand manner. In particular, I realized that visual judgment ability, spatial judgment ability, and descriptive ability are very important, and I was trained while working while devising how to communicate and how to construct the layout. I felt like I was there. Given the size and the number of characters, how to convey the necessary information was the most difficult part of this training. Also, how to output what you input will be different for the same exhibit. Therefore, I realized that it is possible to create more diverse posters by having multiple 

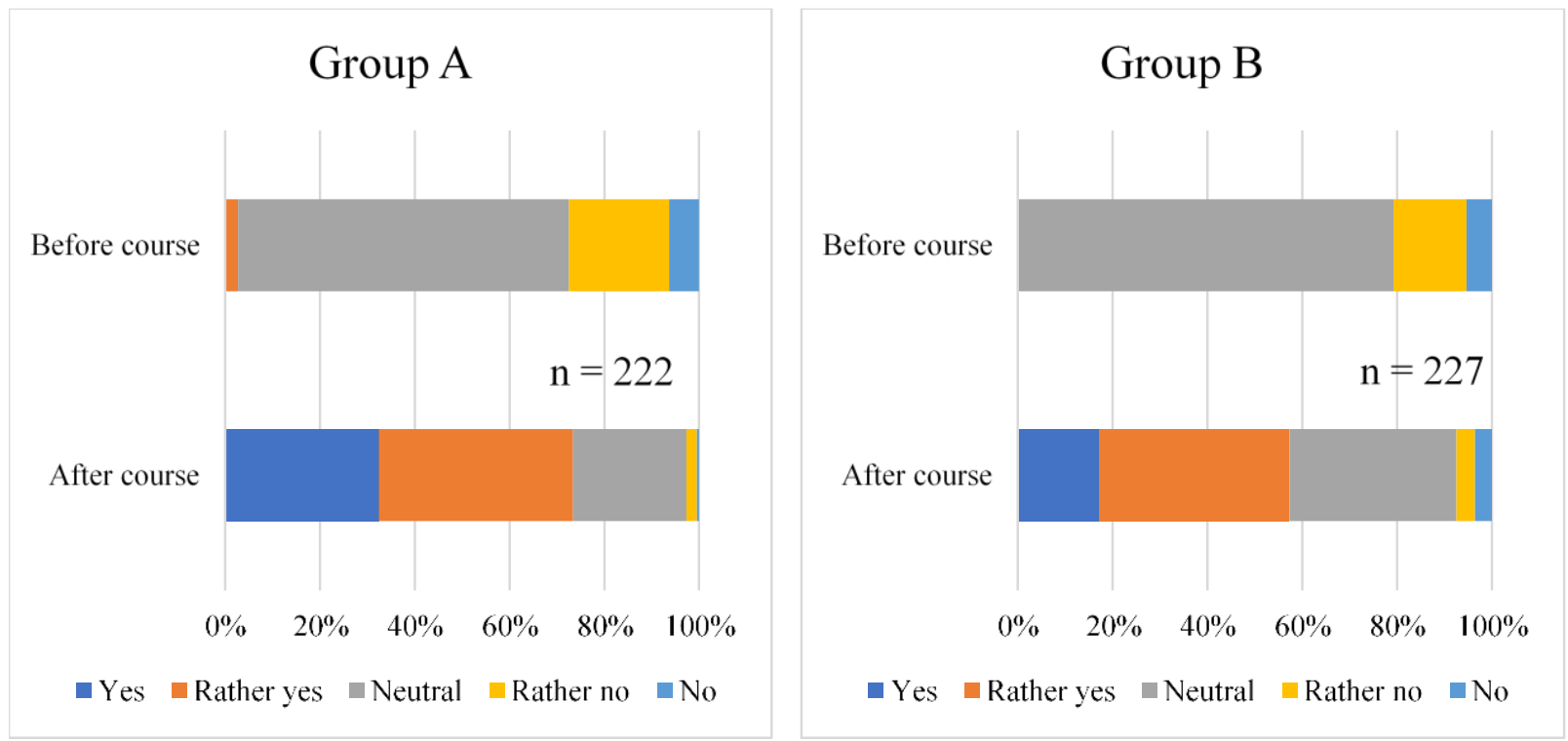

Figure 3. Quantification of Q1 question
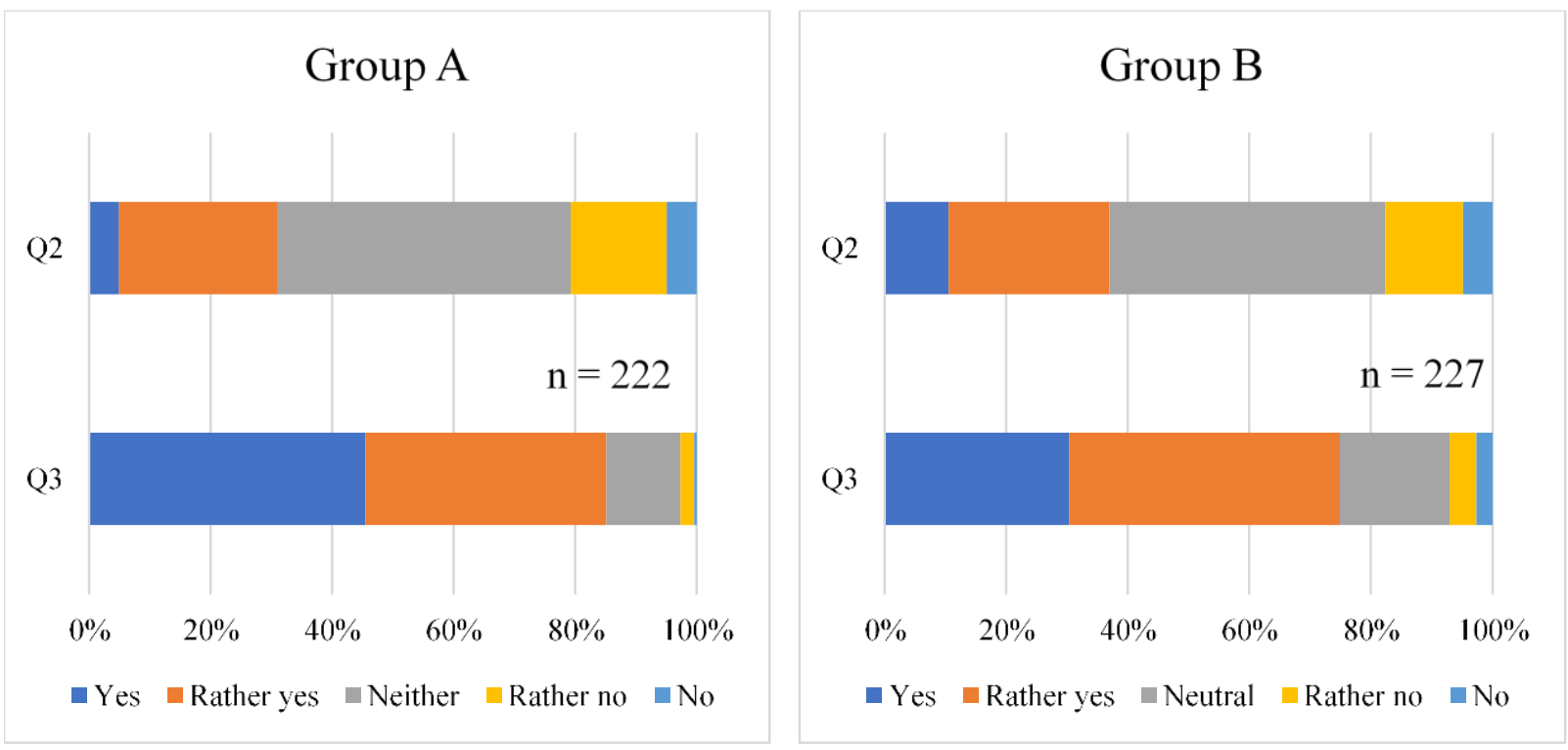

Figure 4. Quantification of Q2 and Q3 question

people exchange opinions and work as in this training. One of the communication effects expected from $\mathrm{OBL}$ is to facilitate dialog smoothly. This time, I was naturally conducting communication through things, and I realized later. It was fun to be able to actively discuss how to interpret the target object and how to explain it through the practical training. Furthermore, I feel that collaboration and integration of different fields will become more important in the future. This time, I have learned that by grasping a certain thing from different perspectives, we can bring out a different aspect from what we have seen before. In Japan, production has decreased and sericulture is declining, but I felt that it would be possible to find a new way of life by combining it with new technologies. For example, we are developing medical materials such as silk and new materials such as cosmetic materials, developing medical products such as vaccines against intractable diseases using genetically engineered silkworms, and producing fluorescent-colored raw silk. There was a group that introduced it, but I thought it was important to introduce such efforts to the general public in an easy-to-understand manner. OBL will be effective for disseminating such knowledge widely. In addition, if there are workshops in which many people from different fields introduce one exhibit in relation to their own 
specialized field (or an area of interest), it is possible to grasp the exhibits from multiple angles. Moreover, since information can be shared through communication with people from different fields, I think that the value of collaboration and integration in different fields can be greatly increased.

\section{DISCUSSION}

To achieve a sustainable future, this study proposes that cultivating OBL in a manner so far, such as a museum setting, can play a pivotal role in interdisciplinary STEAM education, which can be accelerated using original art collections and objects housed at science university museums in Japan. In fact, OBL can evidently stimulate student motivation through authentic sericulture ukiyo-e by multisensory engagement and academic interaction. Additionally, the cross-disciplinary interaction added to new knowledge for students. In particular, in the curating workshop, utilizing sericulture ukiyo-e as objects proved effective as it was the students' first experience and none majored in arts. Therefore, a scenario where particular students led the work in the curating workshop was avoided.

Quantitative analysis of the result of Q1 indicated that the development of interest for sericulture ukiyo-e mainly increased through multisensory activities, such as seeing and touching objects, during the curating workshop. The results of Q2 and Q3 demonstrated that responses were mainly Rather yes or Neutral. The results for Q3 indicated that the students enjoyed interacting with their counterparts majoring in different disciplines and learning with material objects, such as the original artwork of sericulture ukiyo-e.

Alternatively, qualitative analysis reveals that students focused on the beauty and value of sericulture ukiyo-e from the perspective of arts, whereas they viewed the utilization of silk and silkworm from the perspective of science. Through multisensory activities, academic interaction fostered delivery skills, communication skills, and knowledge on advanced technology for problemsolving. Although OBL was recognized as a significant learning method, it can contribute to the education of students majoring in engineering. In other words, it can be applied as a cross-disciplinary learning and teaching method through academic interaction with authentic, artistic, and scientific material objects for problem-solving.

\section{CONCLUSION}

Simpson (2019) has proposed that the contemporary revival of OBL can contribute to the broadening of skill sets in students through the interpersonal interactions of object-handling between students at museums. OBL applied in this manner can elevate literacy of discrete types such as visual, partial, or descriptive (linguistic); it can also improve communication skills, comparative analyses, and negotiation abilities. Although OBL has not yet been introduced to the museum educational system in Japan, the current study evidences that OBL can function in a pivotal role in teaching and learning activities undertaken in Japanese universities, particularly in specific disciplines that have an affinity for museums and across disciplines outside museums. Evidently, the reconceived revival of OBL in its present form can facilitate interdisciplinary learning. The task to qualify and quantify the effectiveness of OBL for the near future has been assigned. The author of this paper believes that the academic value of OBL would increase if problemsolving activities and discourses are actively initiated through the utilization of collections and objects housed in university repositories.

\section{NOTES}

1-The Department of Biological Production, Department of Applied Biological Science, Department of Environmental Science, Department of Natural Resource Science, Department of Ecoregion Science, and Cooperative Department of Veterinary Medicine.

2-The Department of Biotechnology and Life Sciences, Department of Biomedical Engineering, Department of Applied Chemistry, Department of Applied Physics and Chemical Engineering, Department of Mechanical Systems Engineering, and Department of Electrical Engineering and Computer Science.

\section{REFERENCES}

Allen, S. (2004). Designs for learning: Studying science museum exhibits that do more than entertain. Science Education, 88(1), S17-S33. https://doi.org/10.1002/sce.20016

Breiner, J. M., Harkness, S. S., Johnson, C. C., \& Koehler, C. M. (2012). What is STEM? A discussion about conceptions of STEM in education and partnerships, School Science and Mathematics, 112(1), 3-11. https://doi.org/10.1111/j.1949-

8594.2011.00109.x

Bryan, L. A., Moore, T. J., Johnson, C. C., \& Roehrig, G. H. (2015). Integrated STEM education, (Eds.) Johnson, C. C., Peters-Burton, E. E. \& Moore, T. J. STEM road map: A framework for integrated STEM education, 23-27. New York: Routledge. 
Bybee, R. W. (2010). What is STEM education? Science, 329(5995) 996, https://doi.org/10.1126/science.1194998

Chatterjee, H. J. (2010). Object-based learning in higher education: The pedagogical power of museums. Proceedings of the 9th Conference of the International Committee of ICOM for University Museums and Collections, 179-182.

Chatterjee, H. J., Hannan, L., \& Thomson, L. (2015). An introduction to object-based learning and multisensory engagement. In H. J. Chatterjee \& L. Hannan (Eds.), Engaging the senses: Object-based learning in higher education (pp. 1-20). London: Routledge.

Duhs, R. (2010). Learning from university museums and collections in higher education: University College London (UCL). University Museums and Collections Journal, 3, 183-186.

Falk, J. D., \& Dierking, L. D. (2000). Learning from museum: Visitor experiences and the making of meaning. Lanham, MD: AltaMira Press.

Eccles, K. (2019). University museums and digital cabinets: A mobile cultural commons for objects and learning. Book of Abstracts, UMAC Tokyo Seminar, 13.

Hannan, L., Duhs, R., \& Chatterjee, H. J. (2013). Objectbased Learning: A powerful pedagogy for higher education. In A. Boddington, J. Boys, \& C. Speight (Eds.), Museums and higher education working together: Challenges and opportunities (pp. 159168). London: Routledge.

Hooper-Greenhill, E. (2007). Museums and education: Purpose, pedagogy, performance. London: Routledge.

Horn, M. S., Leong, Z. A., Block, F., Diamond, J., Evans, E. M., Phillips, B., \& Shen, C. (2012). Of BATs and APEs: An interactive tabletop game for natural history museums, Proceedings of the 2012 ACM annual conference on Human Factors in Computing Systems, 2059-2068.

Jacobs, C. J., Andrews, J., Castle, M. C., Meister, N., Green, W., Olson, K., Simpson, A. \& Smith, R. (2009). Beyond the field trip: Museum literacy and higher education. Museum Management and Curatorship, 24(1), 5-27.

Jones, N. (2012). Science in three dimensions: The print revolution. Nature, 487(7405), 22-23, https://doi.org/10.1038/487022a

Kador, T., Hannan, L., Nyhan, J., Terras, M., Chatterjee, H. J., \& Carnall, M. (2018). Object-based learning and research-based education: Case studies from the UCL curricula. In J. P. Davies, \& N. Pachler (Eds.), Teaching and Learning in Higher Education (pp. 157-176). London: UCL IOE Press.

Kolb, D. A. (1984). Experiential learning: Experience as the source of learning and development. Englewood Cliffs, NJ: FT Press.

Liao, C. (2016). From interdisciplinary to transdisciplinary: An arts-integrated approach to
STEAM education. Art Education, 69(6), https://doi.org/10.1080/00043125.2016.1224873

Lourenço, M. C. (2008). Where past, present and future knowledge meet: An overview of university museums and collections in Europe. Museologia Scientifica Memorie 2, 321-329.

Marie, J. (2010). The role of object-based learning in transferable skills development. University Museums and Collections Journal, 3, 187-190.

Moore, E. H. (1903). On the foundations of mathematics 1903, Science, 17(428), 401-416. https://doi.org/10.1126/science.17.428.401.

Mujtaba, T., Lawrence, M., Oliver, M. and Reiss, M. (2018). Learning and engagement through natural history museums. Studies in Science Education, 54(1), 41-67. https://doi.org/10.1080/03057267.2018.1442820

National Research Council (2012). A framework for K12 science education: Practices, crosscutting concepts, and core ideas. Washington, DC: National Academies Press.

Nykänen, P., Rothermel, B., \& Simpson, A. (2018). Global issues for university museums. University Museums and Collections Journal, 10, 8-9.

Paris, S. G. (2002). Perspectives on object-centred learning in museums. London: Routledge.

Rillero, P., Koerner, A., Daragmeh, A. K., \& Soyka, K. (2020). Active learning methodologies in a solar power, middle-grade curriculum for Palestinian schools. Interdisciplinary Journal of Environmental and Science Education, 16(2), e2211.

Rolling Jr., J. H. (2016). Reinventing the STEAM engine for art + design education, Art Education, 69, 4-7, 2016.

https://doi.org/10.1080/00043125.2016.1176848

Sand, A., Thoms, B., Davis, E., Pumphrey, D., \& Kinkead, J. (2017). Curating exhibitions as undergraduate research. Council on Undergraduate Research Quarterly, 37(4), 12-18.

Sanders, M. (2009). STEM, STEM education, STEM mania. Technology Teacher, 68(4), 20-26.

Segarra, V. A., Natalizio, B., Falkenberg, C. V., Pulford, S., \& Holmes, R. M. (2018). STEAM: using the arts to train well-rounded and creative scientists. Journal of Microbiology \& Biology Education, 19(1), 1-7. https://doi.org/10.1128/jmbe.v19i1.1360.

Semper, R. J. (1990). Science museums as environments for learning. Physics Today, 43(11), 50-56.

Shanahan, M.-C., Carol-Ann Burke, L. E., \& Francis, K. (2016). Using a boundary object perspective to reconsider the meaning of STEM in a Canadian context. Canadian Journal of Science, Mathematics and Technology Education 16(2), 129-139.

Sharp, A., Thomson, L., Chatterjee, H. J., \& Hannan, L., (2015) The value of object-based learning within and between higher education disciplines. Engaging the Senses: Object-based learning in higher 
education (pp. 97-116). Farnham: Ashgate

Publishing.

Simpson, A. (2014). Rethinking university museums:

Material collections and the changing world of

higher education. Museums Australia Magazine, 22(3), 18-22.

Simpson, A. (2019). Object-based learning: Past paradigms and manifold modalities. Book of Abstracts, UMAC Tokyo Seminar, 11.

Simpson, A., Fukuno, A. \& Minami, H. (2019). University museums and collections as cultural hubs: the future of tradition. University Museums and Collections Journal 11: 8-10.

Simpson, A., \& Hammond, G. (2012). University collections and object-based pedagogies. University Museums and Collections Journal, 5, 75-81. https://doi.org/10.18452/8724

Takeuchi, M. A., Sengupta, P., Shanahan, M.-C., Adams, J. D., \& Hachem, M. (2020). Transdisciplinarity in STEM education: A critical review. Studies in Science Education, 56(2), 213-253.

Thogersen, J., Simpson, A., Hammond, G., Janiszewski, L., \& Guerry, E. (2018). Creating curriculum connections: A university museum object-based learning project. Education for Information, 34(2), 113-120.

Vasquez, J. A., Sneider, C. and Comer, M. (2013). STEM Lesson essentials, grades 3-8: Integrating Science, Technology, Engineering, and Mathematics, Heinemann.

Yoon, S. Y., Dyehouse, M., Lucietto, A. M., Diefes-Dux, H. A., \& Capobianco, B. M. (2014). The effects of integrated science, technology, and engineering education on elementary students' knowledge and identity development. School Science and Mathematics, 114(8), 380-391.

Wilson, P. F., Stott, J., Warnett, J. M., Attridge, A., Smith, M. P., \& Williams, M. A. (2017). Evaluation of touchable 3D-printed replicas in museums. Curator: The Museum Journal, 60(4), 445-465. https://doi.org/10.1111/cura.12244 